\title{
VARIATION IN THE TRACHEOIDS OF SEEDS FROM THE SUBTRIBE Pithecoctenitinae (Bignonieae: Bignoniaceae) And their CONTRIBUTION TO THE SYSTEMATICS OF THE GROUP
}

\author{
Carlos Manuel Burelo-Ramos ${ }^{1}$, Francisco Gerardo lorea-Hernández ${ }^{2}$ \\ AND Guillermo AnGeles ${ }^{3,4}$ \\ ${ }^{1}$ Herbario UJAT, División Académica de Ciencias Biológicas. Universidad Juárez Autónoma de Tabasco \\ ${ }^{2}$ Instituto de Ecología, A.C. Red de Biodiversidad y Sistemática \\ ${ }^{3}$ Instituto de Ecología, A.C., Red de Ecología Funcional \\ ${ }^{4}$ Corresponding author: guillermo.angeles@inecol.edu.mx
}

\begin{abstract}
The diversity of ornamentations present in the tracheoids of seed surface from species of the subtribe Pithecocteniinae (genera Amphilophium, Distictella, Distictis, Glaziovia, Haplolophium, and Pithecoctenium) in the Bignoniaceae is described. Three distinct ornamentation types were observed on the tracheoid surfaces: (1) Tracheoids without ornaments (in the genera Amphilophium, Glaziovia and Haplolophium), (2) ornaments in true helices (in the genera Distictis and Distictella), and (3) ornaments in pseudo-helices (in the genus Pithecoctenium). The taxonomic value of these tracheoid ornaments to establish possible relationships within the subtribe Pithecocteniinae is discussed.
\end{abstract}

Key words: Bignoniaceae, cell-wall thickening, Pithecocteniinae, tracheoids, winged seeds.

Resumen: Se describe la diversidad de ornamentaciones presentes en los traqueoides de las semillas de especies de la subtribu Pithecocteniinae (Bignoniaceae), la cual incluye a los géneros Amphilophium, Distictella, Distictis, Glaziovia, Haplolophium y Pithecoctenium. Se observaron tres tipos de ornamentación sobre las superficies de los traqueoides: (1) Traqueoides sin ornamentaciones en tres géneros (Amphilophium, Glaziovia y Haplolophium), (2) ornamentaciones formando hélices verdaderas (en los géneros Distictis y Distictella) y (3) ornamentaciones en pseudo-hélices (en el género Pithecoctenium). Se discute el posible valor taxonómico de las ornamentaciones de los traqueoides seminales dentro de la subtribu.

Palabras clave: Bignoniaceae, engrosamiento de pared celular, Pithecocteniinae, semillas aladas, traqueoides.

$\mathbf{P}$ lants have multiple dispersal mechanisms; apparently, they have arisen as ecological adaptations that provide a species with the opportunity to distribute its seeds to wider areas, thus increasing the possibility of occupying such sites under favorable germination conditions (Werker, 1997). Seed dispersal can be classified using several criteria, such as the dispersive mechanism, the type of dispersal unit, and the dispersive agent itself. Although no classification system is ideal, the one based on dispersive agent is the most practical and has been used by several authors (Ridley, 1930; Fahn and Werker, 1972; van der Pijl, 1982; Howe and Smallwood, 1982; Levin et al., 2003). In this system, the wind is considered the best agent due to a phenomenon known as anemocory. This mechanism is favored by intrinsic characteristics of seed morphology and anatomy such as small size, low weight, and presence of accessory structures such as wings and feathers that keep it afloat in air currents (Werker, 1997). Anatomically, it has been shown that seed wings are an extension of one or all of seed coat layers, although on rare occasions it is formed by interwoven exotestal hairs (Werker, 1997). Winged seeds are common, among other families, in the Bignoniaceae, Scrophulariaceae, and Vochysiaceae (Cronquist, 1981; Werker, 1997).

In the family Bignoniaceae, the seed wing is made up of "tracheoids", a term used to refer to tracheid-like cells that exhibit diverse ornamentation on their secondary wall, just 
as there are variations in the tracheal elements of the xylem according to the Cornerian Terminology (Schmid, 1986). Such degree of diversity as that found in the cell wall ornamentations of tracheoids has not been reported for any other structure in this family (Von Guttenberg, 1971; Lersten et al., 2002).

Melchior (1927) established the subtribe Pithecocteniinae, including the genera Amphilophium, Distictis, and Pithecoctenium, all characterized by having hexagonal branches and trifid tendrils. Phylogenetic analyses based on molecular (Lohmann, 2006) and morphological (Burelo and Lorea, in prep.) characters seem to indicate that these three genera, plus Distictella, Glaziovia, and Haplolophium form a monophyletic group (the subtribe Pithecoteniinae), comprising 49 species (Gentry, 1973, 1974, 1976, 1993; Pool, $2007 \mathrm{a}, \mathrm{b}, 2009)$. The phylogenetic relationships within this group, established by Lohmann (2006), are not resolved definitely, given the low number of species of the group she used in her study (11 species, of a total of 49).

Lersten et al. (2002) studied the seed wing structure of 20 Bignoniaceae species and described in detail the tracheoid characteristics found in them. In their study, they included some species of the subtribe Pithecocteniineae, namely,
Amphilophium paniculatum (L.) Kunth, Distictella magnoliifolia (Kunth) Sandw., and Pithecoctenium crucigerum (L.) A.H.Gentry. They found several thickening patterns in the secondary wall of tracheoids of seed wings in the Bignoniaceae, a diversity as rich as that found in the tracheary elements of the xylem. From that finding, it is not difficult to imagine the great opportunity offered by such simple system to explore the possibilities of exploiting these traits as a tool for species identification. On the basis of their results, the present research expanded the survey within the six genera of the subtribe Pithecocteniinae and assesses the taxonomic value of tracheoid features present in the seeds of this subtribe.

\section{Materials and methods}

Herborized seed samples from 22 species of the genera Amphilophium, Distictella, Distictis, Glaziovia, Haplolophium, and Pithecoctenium were analyzed (Appendix 1). Five out of the eight Amphilophium species, seven of the eighteen Distictella, four of the eleven Distictis, the only Glaziovia species, and all four of Pithecoctenium species were included. For Haplolophium only one of the four spe-
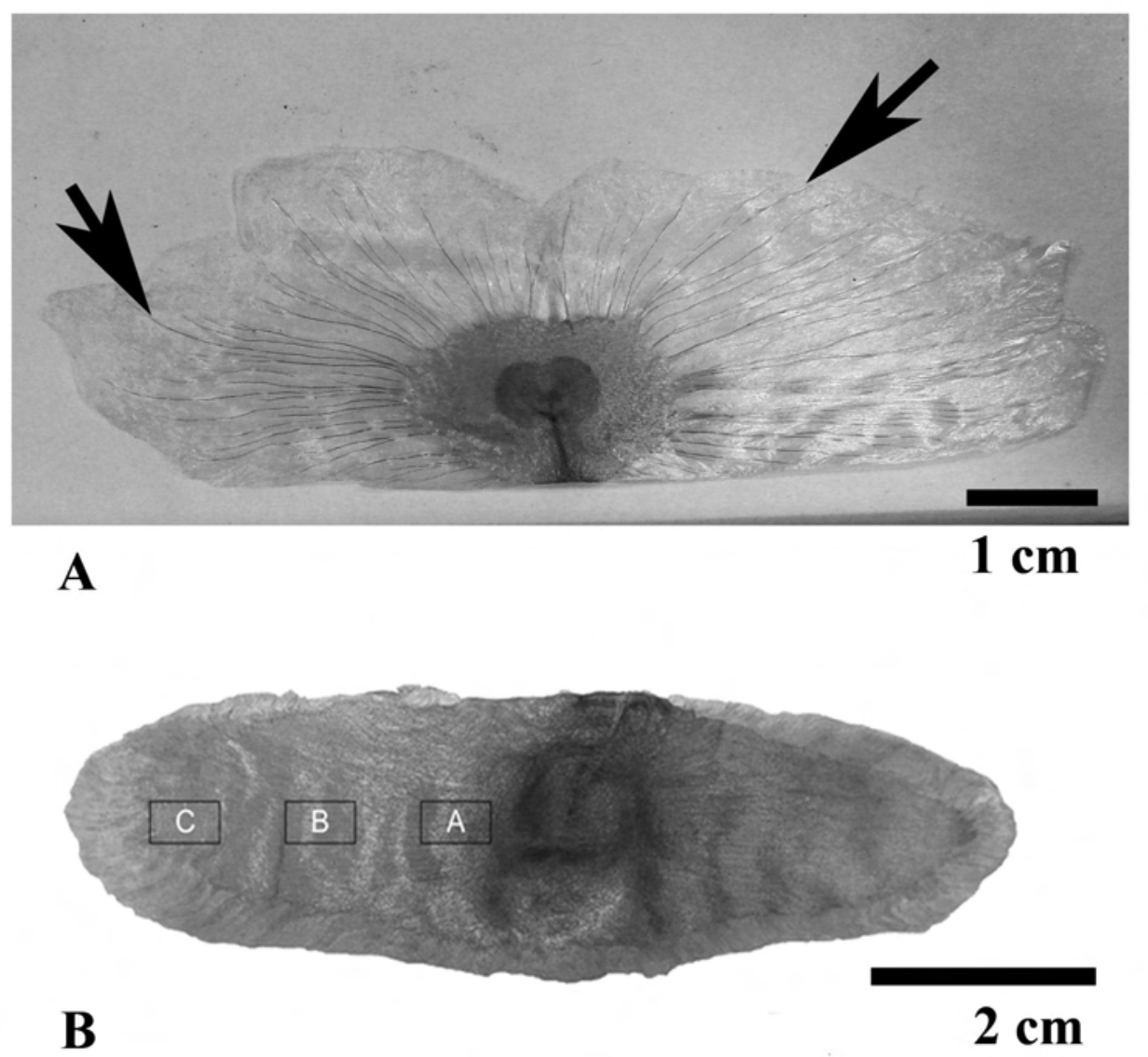

Figure 1. Morphology of a winged seed of Pithecocteniinae, showing the sections of the wing analyzed in this research. The embryo is located in the dark spot toward the center of the seed. A. Thin, membranaceous wing. B. Thicker, papyraceous wing. Arrows indicate the tracheoid extending close to the wing's margins. Squares marked A-C correspond to the areas surveyed in the study (see text). 


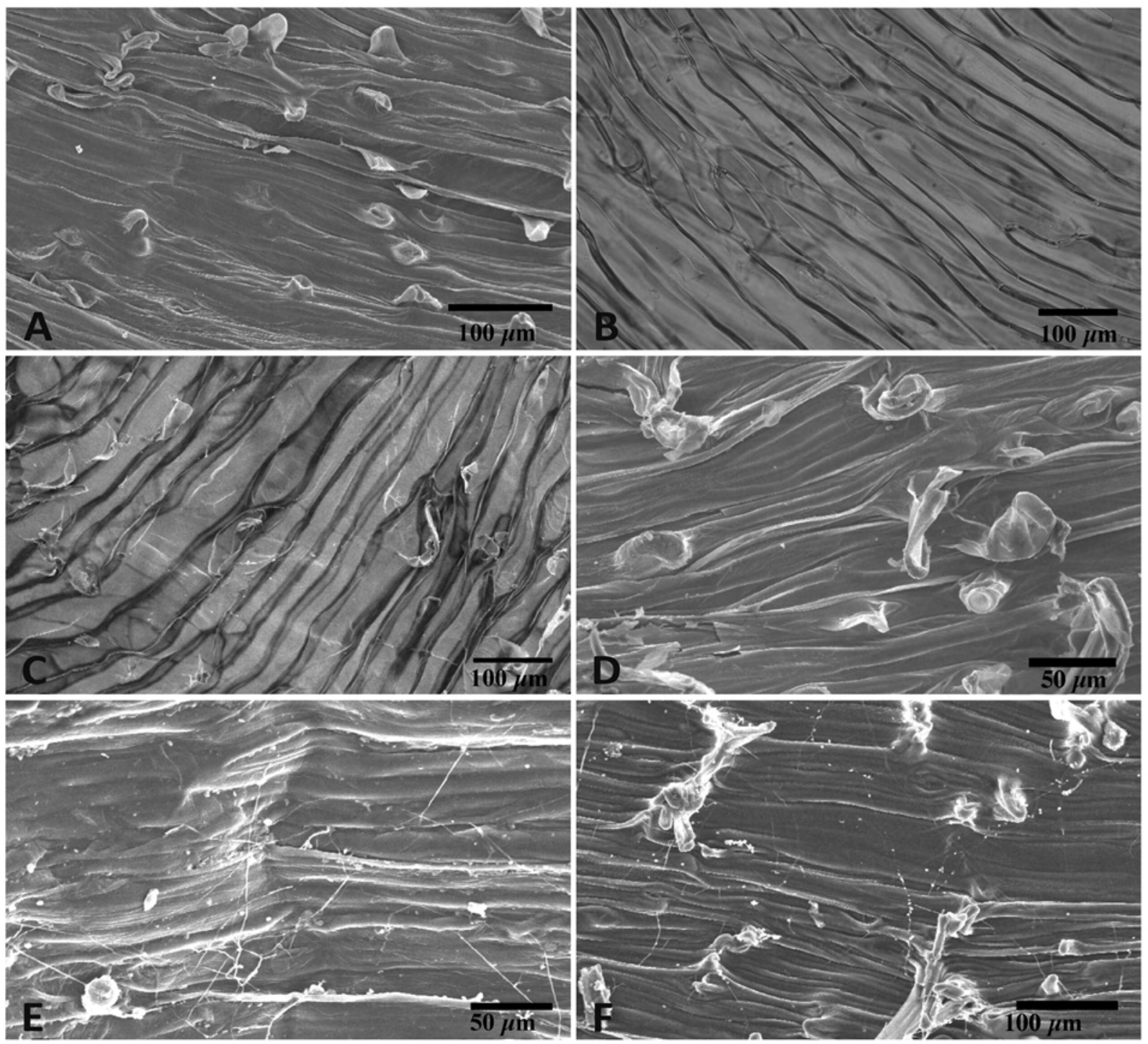

Figure 2. Surface view of seed wings of (A) Amphilophium paniculatum var. molle. Scale bar = $100 \mu$ m. Zone A; (B) A. paniculatum var. imatacense. Scale bar $100 \mu \mathrm{m}$. Zone A; (C) A. pannosum. Scale bar = $100 \mu \mathrm{m}$. Zone C; (D) A. aschersonii. Scale bar = 50 $\mu \mathrm{m}$. Zone C; (E) Glaziovia bahuiniodes. Scale bar $=50 \mu \mathrm{m}$. Zone B; (F) Haplolophium glaziovii. Scale bar $=100 \mu \mathrm{m}$. Zone A.

cies was studied, because it was impossible to obtain seeds from the other three species (since for these, neither fruits nor seeds have been collected yet).

Light Microscopy (LM). The clearing technique proposed by Lersten et al. (2002) was employed with some modifications. Seeds were rehydrated, placed in $\mathrm{NaOH}$ for 15 $\mathrm{min}$, immersed in 5\% sodium hypochlorite for $15 \mathrm{~min}$, and washed in ethanol; the wing tissue was separated from the seed body and divided in three parts, as illustrated in Figure 1. Samples were mounted in synthetic resin and observed with the light microscope. Photomicrographs were taken at several magnifications.

Scanning Electron Microscopy (SEM). Fragments from the three regions of the seed wing indicated in Figure 1 were removed. Afterwards they were placed on a brass microscope sample holder, sputter-coated with gold-palladium in a JEOL Fine Coat JFC-1100 device, and then observed and photographed at various magnifications under a JEOL JSM $5600 \mathrm{LV}$ electron microscope.

\section{Results}

Anatomy. Analysis of seed wings revealed that tracheoids are distributed throughout the wing body, but the largest numbers of them are concentrated at the wing base, because the way tracheoids extend outwards, in a fan-like pattern (Figure 1). Patterns of tracheoid wall ornamentation do not appear to be influenced by size, texture, or wing shape. 

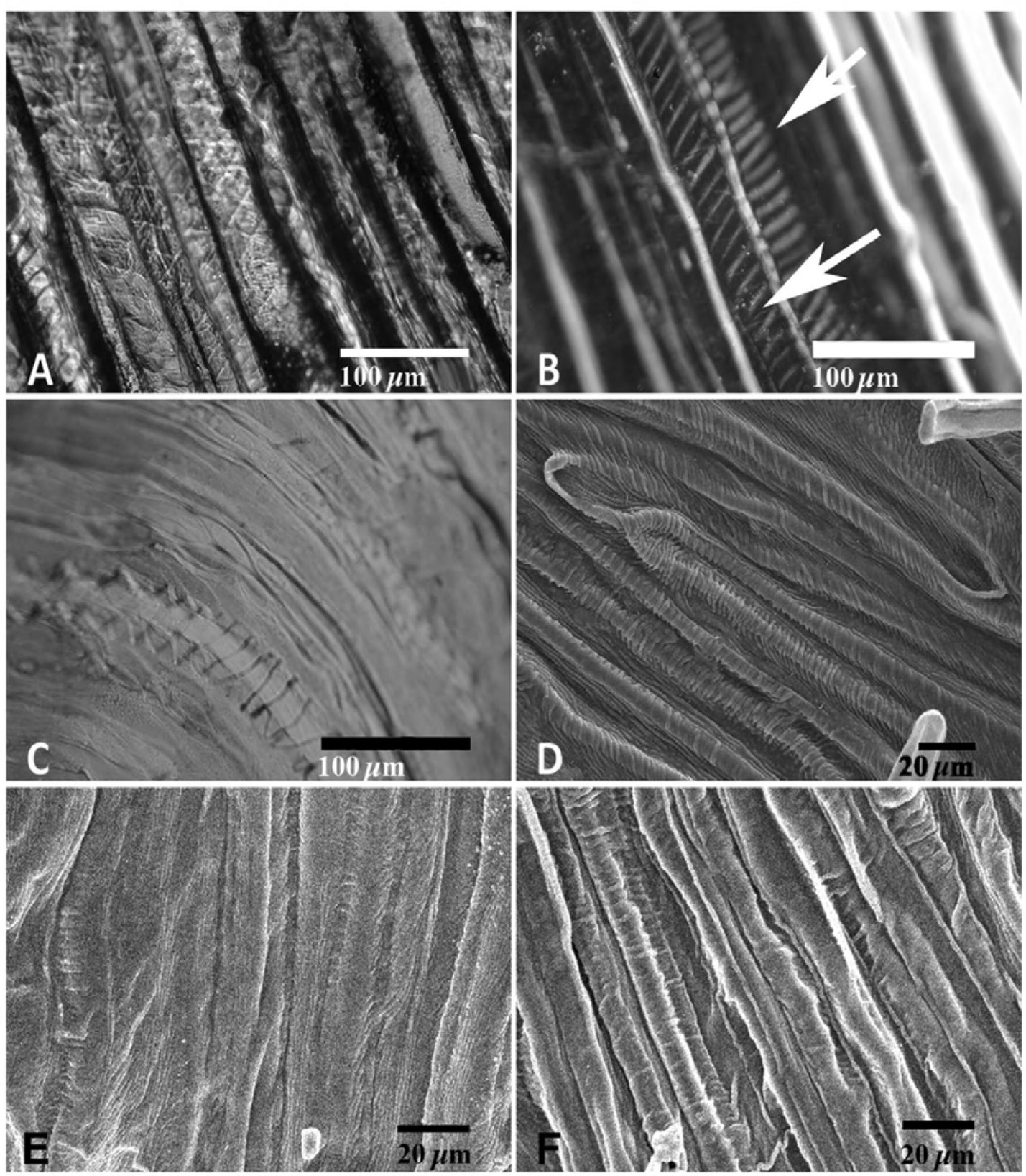

Figure 3. Surface view of the seeds of (A) Distictella obovata. Scale bar $=0.1 \mathrm{~mm}$. Zone A; (B) Distictella obovata. Scale bar $=100 \mu \mathrm{m}$. Zone C; (C) Distictis granulosa. Scale bar $=100 \mu \mathrm{m}$. Zone B; (D) D. granulosa. Scale bar $=20 \mu \mathrm{m}$. Zone A; (E) D. gnaphalantha. Scale bar $=20 \mu \mathrm{m}$. Zone A; (F) D. lactiflora. Scale bar $=20 \mu \mathrm{m}$. Zone B. Arrows point to two tracheoids with helical thickenings.

Three types of tracheoid ornamentation were found:

1.- Tracheoids with smooth cell wall, i.e. lacking ornamentations; found in Amphilophium, Glaziovia, and Haplolophium (Figure 2).

2.- Tracheoids with ornamentations, may be of two types, according to Esau (1977):

2a.- Helical thickening. Cell wall thickening is arranged in true helices that make full turns around the tracheoid; found in the species of Distictis and Distictella (Figure 3). Helical thickenings are transversally connected by narrow lines; these may appear as: (i) scattered or (ii) tightly interwoven. In Distictis pulverulenta, D. lactiflora, and D. granulosa helices are observed tightly interwoven or dense, with up to nine helices for each $20 \mu \mathrm{m}$. We call this helix condition "tight" (Figure 3). It is noteworthy that in D. lactiflora, helices are not evenly spaced. The other species of this group exhibit 3-4 helices every $20 \mu \mathrm{m}$; we call this helix condition "lax."

2b.- Pseudo-helical thickenings. These tracheoids have helices that are found only on the external face of the tracheoid. 

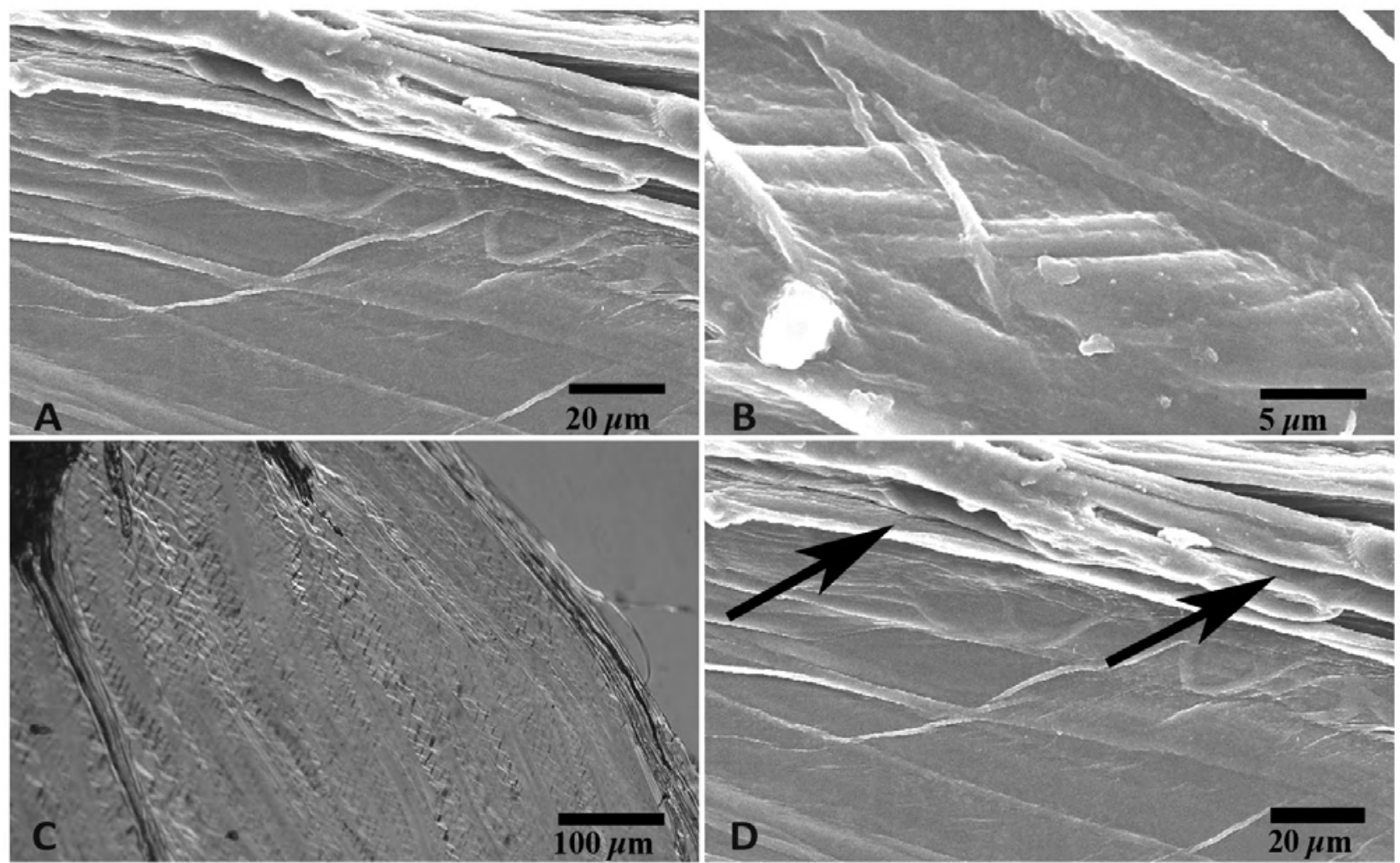

Fig. 4. Surface view of the seeds of (A) Pithecoctenium crucigerum. Scale bar $=20 \mu \mathrm{m}$. Zone A; (B) P. crucigerum. Scale bar $=5 \mu \mathrm{m}$. Zone A; (C) P. cynanchoides. Scale bar $=100 \mu \mathrm{m}$. Zone A; (D) P. cynanchoides. Scale bar $=20 \mu \mathrm{m}$. Zone B.

The ornamentation is not observed in the area where the two tracheoids make contact. Species of the genus Pithecocteni$u m$ have this type of ornamentation (Figure 4).

\section{Discussion}

The three types of tracheoid wall ornamentation found in the subtribe Pithecocteniinae furnish additional information that strengthens former taxonomic hypotheses. The presence of smooth tracheoids in the genera Amphilophium, Glaziovia, and Haplolophium provides new data to support the suggestion that they are closely linked taxonomically (Gentry, 1976). Previous findings indicate that they share a 7-9 aperturate pollen type (Gentry and Tomb, 1979; Burelo et al., 2009) and a strongly lobulate calyx. All this morphological coherence is supported by the results of the phylogenetic study by Lohmann (2006), who identified a strongly supported clade within the Pithecocteniinae formed by these three genera.

Distictis and Distictella, genera that have ornamented tracheoids with complete helices, were originally described as a sole taxon; according to Bureau (1864) and Schumann (1894), the nature of their fruits and seeds is what distinguishes them from other genera in the subtribe. Gentry (1976) suggested that Distictella and Distictis should not be considered separate genera. In this case, Lohmann (2006) found that Distictella is (based on the low number of species surveyed) apparently monophyletic and distinct from Distictis. Anyhow, the presence of helical-thickened walls of tracheoids in the seeds of the species of these genera should be taken into account in future phylogenetic analyses of the subtribe in order to take the best taxonomic decisions.

The genus Pithecoctenium has always been easily identified, with its characteristic 3 to 5 -trifid tendrils. Here, the feature of incomplete helical thickenings on the secondary wall of tracheoids in the species of this genus, clearly distinguish it from the remaining genera in the Pithecocteniinae. Additional characters that help to distinguish the genus Pithecoctenium are the presence of pseudo-helical thickenings such as those described herein, along with some pollen features [inaperturate, with radial symmetry, apolar, spheroidal, with granules within the lumina of the reticulum, and curved, simple-baculate muri (Burelo et al., 2009)] and fruit characters (rounded at the base, with a replum that extends beyond the valves, forming a pointed structure). Only one species of Pithecoctenium was considered by Lohmann (2006) in her phylogenetic study of the Bignonieae, and its relationships to other genera of the Pithecocteniinae are not clear; could it be sister of Distictis or to the Glaziovia-Haplolophium-Amphilophium clade. 
There is no data about the morphology of the tracheoids from species in the sister groups of the Pithecocteniinae. Lersten et al. (2002) included in their study only one species of Anemopaegma, which showed mostly non ornamented cells in the seed wing. Information from Bignonia, Clytostoma, Dolichandra, Macfadyena, Mansoa, Melloa, and Pyrostegia, among other genera, is needed in order to elaborate on the possible evolution of the ornamentation of the tracheoids in the subtribe. Certainly, as concluded by Lersten et al. (2002), in the general picture the ornamentation of tracheoids in seed wings of the Bignoniaceae do not indicate any evolutionary trend of this character in the family. But, there can be such trends within subordinate groups, as can be suspected within the Pithecocteniinae; if tracheoid ornamentation is optimized on the phylogenetic hypothesis of the subtribe (Lohmann, 2006), then one possibility is the trend tracheoid wall with full helical thickenings $\rightarrow$ tracheoid wall with incomplete helical thickenings $\rightarrow$ tracheoid with smooth wall.

Based on current data, tracheoid characteristics appear to be taxonomically important, since they clearly help us to distinguish between genera. Therefore it is suggested to include the tracheoid characteristics in future phylogenetic research, not only of the subtribe Pithecocteniinae, but within the tribe Bignonieae in general, and other tribes as well, like Tecomeae. We suggest these characters to be further analyzed from a morphological and taxonomic perspective, and that in phylogenetic research to be conducted to evaluate their behavior in conjunction with other characters.

Before proposing that the presence of ornamented tracheoids in the seeds of Distictis, Distictella, and Pithecoctenium constitutes an adaptive advantage over the unornamented tracheoids of Amphilophium, Glaziovia, and Haplolophium it is necessary to study and compare their dispersal efficiency and evaluate germination. At first sight it seems that there is no clear relationship between tracheoid ornamentation and ecological adaptation, as there are several species with different tracheoid ornamentation occupying extensive areas and sharing the same habitats; like Amphilophium paniculatum and Pithecoctenium crucigerum that are found from central Mexico down to Brazil.

It has been established that tracheoids have four functions: (1) to channel water flow, (2) to provide resistance against negative pressure, (3) to give structural support, and (4) to provide cells with flexibility (Lersten et al., 2002). Wing tracheoids should therefore be the subject of research that might link their ornamentation type to germination rates, seed dispersal distance, resistance to dehydration, and other factors among species.

\section{Acknowledgments}

We are grateful to the Instituto de Ecología, A.C. and the following organizations for funding the doctoral studies of the first author: Consejo Nacional de Ciencia y Tecnología (CONACyT; scholarship number 157797) and the Universidad Juárez Autónoma de Tabasco for support through the 2002 Institutional Academic Advancement Program. We thank the herbaria JBR, MEXU, NY, UEC and XAL for the loan of specimens and their facilities. Thanks to Mr. Tiburcio Láez Aponte for its technical assistance in SEM and for editing the figures. Three anonymous reviewers provided key suggestions that helped to improve the quality of the manuscript.

\section{Literature cited}

Bureau L.E. 1864. Monographie des Bignoniacées: Ou Histoire Générale et Particulière des Plantes qui Composent Cet Ordre Naturel. J.-B. Baillière et fils, Paris.

Burelo-Ramos C.M., Lorea-Hernández F.G. and Vovides A.P. 2009. Palynological survey of subtribe Pithecocteniinae (Bignonieae, Bignoniaceae). Botanical Journal of the Linnean Society 159:155-162.

Cronquist A. 1981. An Integrated System of Classification of Flowering Plants. Columbia University Press, New York.

Esau K. 1977. Anatomy of Seed Plants. John Wiley and Sons, New York.

Fahn A. and Werker E. 1972. Anatomical mechanisms of seed dispersal. In: Kozlowski T. T. Ed. Seed Biology: Importance, Development, and Germination, pp. 151-221, Academic Press, New York.

Gentry A.H. 1973. Generic delimitations of Central American Bignoniaceae. Brittonia 25:226-242.

Gentry A.H. 1974. Studies in Bignoniaceae 11: A synopsis of the genus Distictis. Annals of the Missouri Botanical Garden 61:494-501

Gentry A.H. 1976. Studies in Bignoniaceae 19: Generic mergers and new species of South American Bignoniaceae. Annals of the Missouri Botanical Garden 63:46-80.

Gentry A.H. 1993. A Field Guide to the Families and Genera of Woody Plants of Northwest South America: (Colombia, Ecuador, Peru): With Supplementary Notes on Herbaceous Taxa. The University of Chicago Press, Chicago.

Gentry A.H. and Tomb A.S. 1979. Taxonomic implications of Bignoniaceae palynology. Annals of the Missouri Botanical Garden 66:756-777.

Howe H.F. and Smallwood J. 1982. Ecology of seed dispersal. Annual Review of Ecology and Systematics 13:201-228.

Lerstern R.N, Krueger L. and Curtis J.D. 2002. Tracheoid variation among Bignoniaceae seed wings with emphasis on Campsis radicans. International Journal of Plant Science 163:369-378.

Levin S.A., Muller-Landau H.C., Nathan R., and Chave J. 2003. The ecology and evolution of seed dispersal: a theoretical perspective. Annual Review of Ecology, Evolution, and Systematics 34:575-604.

Lohmann L.G. 2006. Untangling the phylogeny of neotropical lianas (Bignonieae, Bignoniaceae). American Journal of Botany 93:304-318.

Melchior H. 1927. Der natürliche Formenkreis de Pithecocteniinae innerhalb der Familie der Bignoniaceae. Repertorium Specierum Novarum Regni Vegetabilis. Beihefte 46:71-82. 
Pool, A. 2007a. A review of the genus Distictis (Bignoniaceae). Annals of the Missouri Botanical Garden 94:791-820.

Pool, A. 2007b. A revision of the genus Pithecoctenium (Bignoniaceae). Annals of the Missouri Botanical Garden 94:622-642.

Pool, A. 2009. A review of the genus Distictella (Bignoniaceae). Annals of the Missouri Botanical Garden 96:286-323.

Ridley H.N. 1930. The Dispersal of Plants Throughout the World. L. Reeve \& Co., Ashford.

Schmid R. 1986. On Cornerian and other terminology of angiospermous and gymnospermous seed coats: Historical perspec- tive and terminological recommendations. Taxon 35:476-491.

Schumann K. 1894. Bignoniaceae. In: Engler A. and Prantl K. Eds. Die Natürlichen Pflazenfamilien IV (3b), pp.189-252, Engelmann Leipzig.

van der Pijl L. 1982. Principles of Dispersal in Higher Plants. Springer Verlag, New York.

Von Guttenberg, H. 1971. Bewegungsgewebe und perzeptionsorgane. Borntraeger, Berlin.

Werker E. 1997. Seed Anatomy. Borntraeger, Berlin.

Recibido: 6 de mayo de 2011

Aceptado: 24 de octubre de 2011 


\section{Appendix 1.}

Amphilophium aschersonii Ule, Berlin 3541 (NY); A. ecuadorense A.H.Gentry, Steyermark 54023 (NY); A. paniculatum (L.) Kunth, Avendaño 683 (XAL); A. paniculatum var. molle (Cham. \& Schltdl.) Standl., Oliva 615 (XAL); Cedillo 1091 (XAL); Amphilophium paniculatum var. imatacense A.H.Gentry, Thomas et al. 4029 (NY); A. pannosum (DC.) Bureau \&. K.Schum., Pittier 959 (NY); A. sandwithii Fabris, Jardim et al. 1998 (NY); Distictella cuneifolia (DC.) Sandwith, Silva 228 (NY); D. elongata (Vahl) Urb. Broadway s/n (NY), Kirizawa 111 (XAL); D. laevis (Sandwith) A.H.Gentry, Ferreira 5808 (NY); D. magnoliifolia (Kunth) Sandwith, Galeano et al. 1049 (NY); D. mansoana (DC.) Urb., Oliveira \& Montovani 109 (XAL); D. monophylla Sandwith, Maguire 30662 (NY); D. obovata Sandwith, Liesner \& Holst 20668 (NY); Distictis buccinatoria (DC.) A.H.Gentry, Boutin 3317 (MEXU); D. gnaphalantha (A.Rich.) Urb., González s/n (XAL); D. granulosa Bureau \& K.Schum., Davidse \& González 21917 (MEXU); D. lactiflora (Vahl) DC., Britten \& Cowell 1268 (NY); Glaziovia bauhinioides Bureau ex Baill., Herringer 1583 (SP); Haplolophium glaziovii (Bureau ex K.Schum.) A. H.Gentry, Rizzini 419 (R); Pithecoctenium crucigerum (L.) A.H.Gentry, Nee \& Taylor 28772 (XAL); Vázquez 108 (XAL); P. cynanchoides DC., Galleto 1025 (XAL); P. dolichoides (Cham.) Bureau ex K. Schum.; Handro s/n (JBR); P. hatschbachii A.H.Gentry, Bernacci 25905 (UEC). 